\title{
SISTEM JAMINAN SOSIAL NASIONAL BIDANG KESEHATAN DI ERA OTONOMI DAERAH
}

\author{
Justriany Koni, Ngadino, Anggita Doramia Lumbanraja \\ Program Studi Magiter Kenotariatan, Universitas Diponegoro \\ Fakultas Hukum, Universitas Diponegoro \\ Email: justrianykoni@yahoo.co.id
}

\begin{abstract}
District / City Government policies in the health sector should also support national policies in the National Social Security System stipulated by Law Number 40 of 2004 concerning the National Social Security System, the implementation of which is stipulated by Law Number 24 of 2011 concerning the Social Security Organizing Agency. The approach method used in this research is the Normative Juridical approach. As for the results of this study, among others, FKTP I does not yet have the ability to handle 155 types of diseases as required, both in terms of HR and health infrastructure, but even though FKTP I has not been able to carry out its obligations to the maximum, FKTP I still receives capitation payments from BPJS every month, and BPJS participants are also required to pay dues every month. Weaknesses in the implementation of the Social Security System in the field of health include low public trust, still confusion from the organizers of Health Insurance, increasingly burdening the community, discrimination in services, low quality of services, BPJS payment system, resulting in community disappointment, complicated BPJS service procedures cases, and medicines not funded by BPJS.
\end{abstract}

Keywords : social security; health law ; regional autonomy.

\begin{abstract}
Abstrak
Kebijakan Pemerintah Kabupaten/Kota dalam bidang kesehatan pun seharusnya mendukung kebijakan nasional yang termaktub dalam UU Nomor 40 tahun 2004 tentang Sistem Jaminan Sosial Nasional, dengan pengaturan pelaksanaannya diatur dalam UU Nomor 24 Tahun 2011 tentang Badan Penyelenggara Jaminan Sosial. Metode pendekatan yang digunakan dalam penelitian ini adalah pendekatan Yuridis Normatif. Adapun hasil dari penelitian ini antara lain FKTP I ini belum memiliki kemampuan untuk menangani 155 jenis penyakit sebagaimana yang disyaratkan, baik dari segi SDM maupun sarana prasarana kesehatan, tetapi walaupun FKTP I ini belum bisa menjalankan kewajibannya secara maksimal, FKTP I tetap menerima pembayaran kapitasi dari BPJS setiap bulannya, dan peserta BPJS diwajibkan pula membayar iuran setiap bulannya.Kelemahan-kelemahan pelaksanaan Sistem Jaminan Sosial bidang kesehatan diantaranya masih rendahnya kepercayaan masyarakat, masih adanya kebingungan dari pihak penyelenggara Jaminan Kesehatan, semakin membebani masyarakat, adanya diskriminasi pelayanan, masih rendahnya mutu pelayanan, system pembayaran BPJS,mengakibatkan kekecewaan masyarakat, prosedur pelayanan BPJS yang berbelitbelit, dan obat-obatan yang tidak dibiayai oleh BPJS.
\end{abstract}

Kata kunci : jaminan sosial ; hukum kesehatan ; otonomi daerah. 


\section{A. Pendahuluan}

Secara yuridis hak rakyat untuk mendapatkan pelayanan kesehatan yang layak diatur dalam Pasal 28 H, dan Pasal 34 Undang-Undang Dasar Negara Republik Indonesia Tahun 1945. UndangUndang Nomor 40 Tahun 2004 tentang Sistem Jaminan Sosial Nasional dan Undang-Undang Nomor 24 Tahun 2011 tentang Pembentukan Badan Penyelenggara Jaminan Sosial (BPJS) sertaPeraturan Presiden Nomor 12 Tahun 2013 Juncto Peraturan Presiden Nomor 111 Tahun 2013 tentang Jaminan Kesehatan Nasional adalah bentuk komitmen pemerintah dalam memberikan kesejahteraan (welfare state) berupa jaminan perlindungan kesehatan bagi seluruh rakyat Indonesia.

Menurut Undang-Undang Nomor 23 Tahun 2014 tentang Pemerintah Daerah, bidang kesehatan merupakan salah satu urusan yang menjadi urusan daerah. Hal ini menjadikan pemerintah daerah harus mempersiapkan dan meningkatkan pelayanan di bidang kesehatan secara keseluruhan. Kebijakan Pemerintah Kabupaten/Kota dalam bidang kesehatan pun seharusnya mendukung kebijakan nasional dalam Sistem Jaminan Sosial Nasional yang ditetapkan dengan UU Nomor 40 tahun 2004 tentang Sistem Jaminan Sosial Nasional, yang pelaksanaannya ditetapkan dengan UU Nomor 24 Tahun 2011 tentang Badan Penyelenggara Jaminan Sosial, yang diberlakukan serentak di seluruh Indonesia pada tanggal 1 Januari 2014 (Kertonegoro, 1987).

Penyelenggaraan SJSN Bidang Kesehatan di Kabupaten Kotawaringin Barat belum diatur dalam bentuk Peraturan Daerah tetapi diatur dengan Peraturan Bupati Nomor 2 tahun 2009 tentang Jaminan Kesehatan Dasar Penduduk (Jamkesdasduk), yang disempurnakan dengan Peraturan Bupati Nomor 9 Tahun 2014 tentang Kobar Sehat, Kobar Sehat adalah Jaminan Kesehatan Daerah (Jamkesda), yang merupakan regulasi turunan dari Peraturan Menteri Kesehatan Nomor 28 Tahun 2014 tentang Petunjuk Teknis JKN.

Dalam pelaksanaannya ditemui masalah antara lain ada kecenderungan masyarakat menganggap bahwa BPJS bidang Kesehatan menanggung semua pembiayaan pelayanan kesehatan sesuai keinginan atau kebutuhan riil (Trihono, 2002).

Pada saat ini belum ada Kerjasama dan sinergitas yang baik di antara Badan Penyelenggara Jaminan Sosial (bidang Kesehatan) dengan puskesmas dan/atau rumah sakit sebagai pemberi layanan kesehatan ataupun provider, terutama dalam hal mekanisme rujukan untuk pembagian jasa medis. Hal ini menyebabkan pelaksanaan BPJS kesehatan untuk semua masyarakat baik TNI/ Polri, PNS, masyarakat kurang mampu, masyarakat yang berada di perkotaan dan masyarakat yang berada di pedesaan masih banyak yang mengalami kendala baik dari segi administrasi maupun dari segi teknis. 
Berdasarkan latar belakang di atas, maka penelitian ini mengkaji mengenai pelaksanaan Sistem Jaminan Sosial Nasional Bidang Kesehatan dalam hukum positif dan kelemahan-kelemahan pelaksanaan Sistem Jaminan Sosial Nasional Bidang Kesehatan.

Berdasarkan hasil penelusuran, penulis menemukan beberapa penelitian terdahulu yang sama-sama membahas mengenai perlindungan hukum di bidang pelayanan kesehatan.

Pada tahun 2013, Syarifah Usmandi meneliti tentang pelaksanaan pemberian pelayanan kesehatan bagi masyarakat kurang mampu dan hambatan-hambatan yang dialami dalam pelaksanan pemberian pelayanan kesehatan tersebut serta upaya apa yang dilakukan dalam menangani hambatan tersebut berdasarkan Pasal 19 ayat (2) jo Pasal 21 ayat (1) jo Pasal 22 ayat (1) Undang-Undang Nomor 40 Tahun 2004 Tentang Sistem Jaminan Sosial Nasional di Rumah Sakit Umum Daerah dr. Saiful Anwar Kota Malang (Usman, 2013).

Pada tahun 2015 Deasy N. Paruntu meneliti tentang perlindungan hukum hak kesehatan warga negara berdasarkan Undang-Undang Nomor 24 Tahun 2011 tentang Badan Penyelenggara Jaminan Sosial (Paruntu, 2015).

Pada tahun 2014 Ruby Qumairipada tahun 2014 meneliti tentang sinkronisasi Pasal 36 ayat (2) Peraturan Presiden Nomor 12 Tahun 2013 tentang Jaminan Kesehatan terhadap Pasal 23 ayat (1) Undang-undangNomor 40 Tahun 2004 tentang Sistem Jaminan Sosial Nasional terkait kerja sama dengan Badan Penyelenggara Jaminan Sosial (Qumairi, 2014).

Meskipun penelitian ini sama-sama membahas mengenai perlindungan hukum di bidang pelayanan kesehatan. Namun yang membedakan penelitian ini dengan penelitian terdahulu adalah, artikel ini lebih menekankan pada permasalahan pelaksanaan Sistem Jaminan Sosial Nasional Bidang Kesehatan dalam hukum positif dan kelemahan-kelemahan pelaksanaan Sistem Jaminan Sosial Nasional Bidang Kesehatan.

\section{B. Metode Penelitian}

Metode pendekatan yang digunakan dalam penelitian ini adalah pendekatan yuridis normatif. Dalam penelitian ini menggunakan bahan pustaka atau data sekunder mengenai azasazas hukum serta studi kasus yang dengan kata lain sering disebut sebgai penelitian hukum kepustakaan. Hal ini dikarenakan data penelitian ini berdasarkan pada bahan hukum utama yang dianalisa dengan cara menelaah teori-teori, konsep-konsep, asas-asas hukum serta peraturan perundangan yang berhubungan dengan pelaksanaan Sistem Jaminan Sosial Nasional Bidang Kesehatan di Indonesia. 


\section{Hasil Dan Pembahasan}

\section{Kontruksi Sistem Jaminan Sosial Nasional Bidang Kesehatan Dalam Hukum Positif Saat Ini}

Bangsa Indonesia telah memiliki sistem jaminan sosial bagi seluruh rakyat Indonesia, yang telah diterapkan dalam Undang-Undang Nomor 40 Tahun 2004 tentang Sistem Jaminan Sosial Nasional (SJSN). Dan untuk mewujudkan tujuannya tersebut maka dibentuklah Badan Penyelenggara yang berbadan hukum. Dalam hal inilah yang mendasari pembentukan Badan Hukum sebagai Penyelenggara Jaminan Sosial. BPJS terbagi menjadi 2(dua) yaitu BPJS Kesehatan yang bertugas menyelenggarakan program jaminan kesehatan dan BPJS Ketenagakerjaaan yang bertugas menyelenggarakan program jaminan kecelakaan kerja, jaminan hari tua, jaminan pensiun dan jaminan kematian (Santoso, 2014).

Fungsi, tugas, wewenang, hak dan kewajiban BPJS Kesehatan adalah sebagai wadah atau Badan Hukum Penyelenggara Program JKN yang pada intinya hanya berfungsi sebagai pengelola administrasi Program JKN mulai pendaftaran hingga penerima iuran peserta, melakukan pembayaran kepada FKTP I dan FKTP II, dan pengelola aset BPJS Kesehatan. Namun dalam UU ini tidak ada pasal yang menyebutkan bahwa BPJS Kesehatan bertanggung jawab terhadap pelayanan kesehatan. Pelayanan kesehatan baik fasilitas maupun mutu pelayanan sepenuhnya merupakan tanggung jawab fasilitas kesehatan yang telah ditunjuk.

Dalam penyelenggaraan Badan Penyelenggaraan Jaminan Sosial (BPJS), merupakan satu kesatuan sistem yang tidak dapa dipisahkan dengan fasilitas kesehatan tingkat pertama. Fasilitas kesehatan tingkat pertama kita kenal sebagai puskesmas atau yang setara, praktik dokter atau praktik dokter gigi, ataupun berupa klinik pratama atau yang setara dan rumah sakit tingkat/kelas D pratama atau yang setara sesuai dengan peraturan yang berlaku. Penggolongan ini dilakukan karena adanya keterbatasan penyediaan fasilitas kesehatan tingkat pertama, khususnya pelayanan puskesmas yang ada di daerah (Santoso, 2014).

Upaya kesehatan perseorangan tingkat pertama (UKP TP) perawatan yang diberikan oleh Fasilitas kesehatan tingkat pertama ini meliputi rawat jalan, pelayanan gawat darurat, pelayanan satu hari (one day care), home care, dan/atau rawat inap dengan berdasarkan kebutuhan pelayanan kesehatan tersebut (Yuliani, 2013).

Prinsip dalam penyelenggaraan Puskesmas ini didasarkan pada paradigma sehat, pertanggung-jawaban wilayah, kemandirian masyarakat, pemerataan, teknologi tepat guna dan keterpaduan dan kesinambungan. Sehingga pada dasarny, Puskesmas lebih 
mengutamakan upaya promotif (peningkatan) dan upaya preventif (pencegahan). Menyelenggarakan upaya kesehatan masyarakat (UKM) dan menyelenggarakan upaya kesehatan perseorangan (UKP) di wilayah kerjanya. (Suharto, 2005)

Sehubungan dengan keberadaan BPJS, Puskesmas mendapat peran penting dalam pelaksanaan Program jaminan Kesehatan Nasional. BPJS Kesehatan sebagai penyelenggara program jaminan sosial, dalam pelaksanaan tugasnya diberikan pedoman berupa Peraturan Presiden Nomor 12 tentang Jaminan Kesehatan Juncto Peraturan Presiden Nomor 111 Tahun 2013 tentang Jaminan Kesehatan Nasional. Dalam menyelenggarakan program jaminan kesehatan nasional (JKN), BPJS bekerja sama dengan fasilitas kesehatan yang memenuhi syarat guna memenuhi kebutuhan medis sejumlah peserta, pengiriman tenaga kesehatan, atau penyediaan fasilitas kesehatan tertentu. (Siregar, 2008)

Keberhasilan Jaminan kesehatan sangat ditentukan tersedianya fasilitas kesehatan yang memenuhi standar yang dibutuhkan. Tanpa adanya fasilitas kesehatan yang memenuhi standar maka program jaminan kesehatan tidak berjalan sesuai maksud dan tujuan ditetapkannya UU ini. Penyediaan fasilitas kesehatan ini merupakan wujud tanggung jawab negara sebagaimana diamanatkan Pasal 34 (3) UUD NRI 1945. Berdasarkan Pasal 35 dan 36 Peraturan Presiden Nomor 111 Tahun 2013 tentang JKN tersebut di atas maka menjadi tanggung jawab Pemerintah dan Pemerintah Daerah untuk menyediakan fasilitas kesehatan yang memenuhi standar tersebut dan melakukan kerjasama dengan BPJS Kesehatan.(Yustina, 2012)

Sistem kendali mutu merupakan aspek penting yang harus diperhatikan, mengingat pelayanan yang baik telah menjadi tuntutan masyarakat saat ini. Sedikit saja terjadi ketidaknyamanan pemakai jasa dapat menimbulkan ketidakpuasan masyarakat. Oleh karenanya diatur pula apa yang harus dilakukan jika masyarakat merasa tidak puas dengan pelayanan yang di dapatkan, hal ini diatur dalam Pasal 46 sebagai berikut: "Penyampaian pengaduan sebagaimana dimaksud pada ayat(1) dan ayat (2) harus memperoleh penanganan dan penyelesaian secara memadai dan dalam waktu yang singkat sera diberikan umpan balik ke pihak yang menyampaikan. Penyampaian pengaduan sebagaimana dimaksud pada ayat (3) dilaksanakan sesuai dengan ketentuan peraturan perundang-undangan. Dalam hal peserta tidak puas terhadap pelayanan jaminan kesehatan yang diberikan oleh fasilitas kesehatan yang bekerjasama dengan BPJS Kesehatan, peserta dapat menyampaikan pengaduan kepada fasilitas kesehatan dan/atau BPJS Kesehatan. Dalam hal peserta dan/atau fasilitas kesehatan tidak mendapatkan pelayanan yang baik dari BPJS Kesehatan, dapat menyampaikan pengaduan kepada Menteri” (Suharto, 2005). 


\section{Kelemahan-Kelemahan Pelaksanaan Sistem Jaminan Sosial Nasional Bidang Kesehatan Saat} Ini

Berdasarkan implementasi penyelenggaraan Program Jaminan Kesehatan di Kabupaten Kotawaringin Barat, dapat dilihat bahwa pelaksanaan sistem jaminan sosial belum berjalan sesuai dengan yang diharapkan sebelumnya. Berdasarkan hasil penelitian yang lakukan terhadap pelaksanaan Program Jaminan Kesehatan di Kabupaten Kotawaringin Barat dapat diketahui kelemahan-kelemahan dari penyelenggaran Program Jaminan Kesehatan, yaitu sebagai berikut:

a. Belum adanya Peraturan Daerah yang mengatur tentang Penyelenggaraan Sistem Jaminan Sosial Nasional Bidang Kesehatan di Kabupaten Kotawaringin Barat.

Sehingga penyelenggaraan SJSN Bidang Kesehatan belum memiliki payung hukum dan Kabupaten Kotawaringin Barat juga belum mempunyai Sistem Kesehatan Daerah (SKD). Saat ini penyelenggaraan Program JKN hanya berdasarkan petunjuk teknis dalam bentuk Peraturan Menteri Kesehatan RI Nomor 28 Tahun 2014 tentang Petunjuk Pelaksanaan Program JKN (Dachroni, 2000).

b. Masih rendahnya kepercayaan masyarakat terhadap birokrasi pemerintah.

Dapat terlihat dari masih banyaknya masyarakat yang belum mengikuti Program jaminan Kesehatan di Kabupaten Kotawaringin Barat. Hal tersebut disebabkan belum memadainya sarana dan prasarana BPJS sebagai penyelenggara Program Jaminan Kesehatan di Kabupaten Kotawaringin Barat, dan masyarakat masih banyak yang belum sadar akan pentingnya jaminan perlindungan kesehatan, sehingga masih enggan menggeluarkan uang setiap bulannya untuk membayar iuran program Jaminan Kesehatan Nasional.

c. Masihadanya kebingungan dari pihak penyelenggara program Jaminan Kesehatan.

Hal ini terlihat dari kurang siapnya penyelenggara Jaminan Kesehatan baik terkait dengan mekanisme penyelenggaraan Jaminan Kesehatan maupun masalah-masalah teknis yang terjadi di lapangan, yang pada dasarnya disebabkan karena birokrasi yang terlalu rumit sehingga dalam pelaksanaannya petugas mengalami dilema antara kepatuhan terhadap peraturan dengan kemampuan yang dimiliki.

d. Semakin membebani masyarakat. 
Bagi masyarakat yang tidak mempunyai penghasilan tetap dan tidak termasuk dalam daftar Penerima Bantuan Iuran (PBI) dari Pemerintah, kewajiban membayar iuran kepesertaan bagi setiap jiwa yang terdaftar pada Kartu keluarga setiap bulannya dirasakan semakin membebani. Dari sisi cara pembayaran iuran peserta juga muncul kesulitan. Pembayaran yang harus melalui transfer di Bank, serta kantor BPJS Kesehatan yang terletak di ibukota Kabupaten yang jauh dari jangkauan masyarakat pedesaan, terutama bagi masyarakat golongan menengah kebawah yang tentunya kesulitan untuk memenuhi kebutuhan sehari-hari secara layak. Fasilitas kesehatan yang bermutu saat ini hanya ada di perkotaan khususnya di kota-kota besar.

e. Masih adanya diskriminasi pemberian pelayanan jaminan kesehatan.

Diskriminasi ini terlihat dari penerapan golongan dalam pemberian pelayanan jaminan kesehatan. Adanya pemberlakuan kelas tentunya tidak mengandung unsur keadilan karena pemberian pelayanan bagi kelas I pasti berbeda dengan kelas II maupun kelas III. Pemberian jaminan kesehatan yang bernilai keadilan tentunya harus sama dalam pemberian pelayanan baik bagi kelas I, II dan III, sehingga masyarakat tidak merasa didiskriminasikan dalam pemberian pelayanan jaminan kesehatan.

f. Masih rendahnya mutu pelayanan yang diberikan oleh penyelenggara fasilitas kesehatan tingkat pertama (FKTP I) dan fasilitas kesehatan tingkat lanjutan (FKTP II).

Hal ini tentunya disebabkan karena pembayaran oleh BPJS kepada fasilitas kesehatan menggunakan sistim kapitasi dan sistim INA CBGs yang memberikan tarif sangat minim pada tiap jenis pelayanan, sehingga petugas kesehatan yang berada di fasilitas kesehatan pun hanya mampu memberikan pelayanan yang minim pula.

g. Pembayaran dengan menggunakan sistim kapitasi dan INA CBGs.

Pembayaran dengan sistim kapitasi sangat berdampak pada fasilitas kesehatan yang belum memadai menyebabkan makin rendahnya kepercayaan masyarakat karena Puskesmas selaku FKTP I dibatasi dengan Pedoman pemberian jenis pelayanan dan pemberian obat yang minim, sehingga pasien datang bukan untuk berobat tetapi hanya meminta untuk dibuatkan surat rujukan ke Rumah Sakit sebagai syarat (prosedur) pelayanan. Padahal seharusnya pasien yang dirujuk ke Rumah Sakit hanya pasien yang dengan kasus rujukan spesialis maupun sub speaslistik. Begitu pula pasien yang berobat ke Rumah Sakit (FKTP II) hanya mendapatkan pelayanan dengan pengelompokan 
masing-masing penyakit karena pembayaran BPJS kepada FKTP II menggunakan sistim penghitungan INA CBGs.

h. Prosedur BPJS yang berbelit-belit.

Prosedur BPJS dalam pelayanan belum dapat dilaksanakan sesuai dengan mekanisme yang telah ditetapkan. Hal ini dikarenakan belum tersedianya FKTP I yang dapat memberikan pelayanan seperti yang telah dijanjikan oleh BPJS kepada peserta, sedangkan pasien memerlukan penanganan cepat tetapi tetap harus mengikuti prosedur pelayanan yang telah ditetapkan yaitu harus ke (FKTP I) terlebih dahulu.

i. Obat-obat yang digunakan pasien tidak dapat dibiayai oleh BPJS.

Obat-obat yang diberikan kepada pasien hanya obat yang masuk dalam daftar BPJS, jumlah maupun jenisnya dibatasi, sehingga tidak semua obat yang dibutuhkan pasien dapat dibiayai oleh BPJS. Disamping itu pada pertolongan persalinan hanya ibu dan persalinannya yang ditanggung oleh BPJS, sedangkan bayi tidak di tanggung dan harus didaftarkan sebagai peserta BPJS. Setelah 7 (tujuh) hari sejak pendaftaran baru bisa mendapatkan pelayanan.

j. Masyarakat tidak mau membayar iuran BPJS apabila tidak jatuh sakit.

Menurut Kepala BPJS Kesehatan Cabang Pangkalan Bun, bahwa masih banyak peserta JKN Mandiri yang tidak mau lagi membayar iuran kepesertaan setelah sembuh atau tidak jatuh sakit. Tetapi setelah 3 (bulan) menunggak, BPJS akan menghubungi yang bersangkutan agar melakukan pembayaran kepesertaan tersebut. Menurutnya ada yang langsung membayar dan ada juga yang tetap tidak membayar iuran tersebut. Dijelaskan pula bahwa dengan tidak membayar iuran secara rutin akan menambah beban peserta apabila nanti jatuh sakit, karena peserta tersebut harus membayar seluruh tunggakan ditambah dendanya terlebih dulu baru kartu kepesertaan dapat di aktifkan.

k. Struktur Hukum Jaminan Sosial Nasional Bidang Kesehatan khususnya di FKTP I belum berbasis nilai keadilan,

Hingga saat ini belum ada Puskesmas sebagai FKTP I yang terakreditasi. Diperlukan peningkatkan dan pemisahan manajemen upaya kuratif (pengobatan) dan rehabilitatif (pemulihan) dari manajemen Puskesmas. Dengan pemisahan tersebut manajemen upaya kuratif (pengobatan) dan rehabilitatif (pemulihan) dapat memberikan 
pelayanan kesehatan yang bermutu dan cepat pada masyarakat yang memerlukan pelayanan segera ketika jatuh sakit.

Dengan melihat kelemahan-kelemahan penyelenggaran Sistem Jaminan Sosial Nasional Bidang Kesehatan melalui Program JKN di atas, menurut penulis perlu dilihat dari keefektifan bekerjanya hukum. Sebagaimana di katakan Chambliss-Seidmen bahwa untuk mengukur keefektifan sebuah perundang-undangan bekerja dalam mensejahterakan masyarakat, ditentukan oleh 3 faktor yang mendasar yaitu faktor yuridis normatif yaitu pada saat pembentukannya apakah sudah memenuhi azas filosofis, yuridis maupun sosiologis, kemudian faktor pegakannya apakah sudah sesuai dengan tujuan serta faktor yuridis sosiologisnya artinya apakah Peraturan Perundang-undangan yang di buat dapat di terima masyarakat, dan apakah sudah memberikan manfaat bagi masyarakat (Muchsin dan Putra, 2002).

Faktor yang sangat mempengaruhi bekerjanya sudah peraturan perundang-undangan dalam masyarakat adalah sistem hukum, sebagaimana yang dikatakan Friedman dalam Teori Sistem Hukum bahwa sistem hukum harus mencakup 3 (tiga) komponen hukum yang seimbang. (Friedman, 2009) Keterkaitan dengan Sistem Hukum Sistem Jaminan Sosial Nasional Bidang Kesehatan bahwa ditemukan belum adanya keseimbangan dari ke-3 (tiga) komponen hukumnya sehingga tujuan dari pada dibentuknya Sistem Jaminan Sosial Nasional Bidang Kesehatan melalui Program JKN dengan Kepesertaan BPJS belum dapat efektif mensejahterakan masyarakat.

\section{SIMPULAN}

Dalam praktiknya FKTP I ini belum memiliki kemampuan untuk menangani 155 jenis penyakit sebagaimana yang disyaratkan, baik dari segi SDM maupun sarana prasarana kesehatan, tetapi walaupun FKTP I ini belum bisa menjalankan kewajibannya secara maksimal, FKTP I tetap menerima pembayaran kapitasi dari BPJS setiap bulannya, dan peserta BPJS diwajibkan pula membayar iuran setiap bulannya. Dalam tarif ini pembayaran sudah berdasarkan pengelompokan penyakit dan jenis pelayanan serta obat yang diberikan sesuai dipaketkan seminim mungkin. Hal ini dikeluhkan baik bagi dokter maupun pasien yang sudah resisten terhadap jenis obat yang disediakan. Pengelola aset BPJS kesehatan yang berkedudukan di Kabupaten menyebabkan sebagian besar masyarakat pedesaan masih enggan untuk mendaftarkan diri dikarenakan biaya transportasi yang cukup mahal dibandingkan dengan iuran yang akan disetorkan kepada BPJS. 
Dengan keterbatasan jumlah SDM, maka sosialisasi masih belum dapat di lakukan secara merata kepada masyarakat, sehingga hingga saat ini sebagian masyarakat belum mengetahui tentang manfaat BPJS Kesehatan. Kelemahan-kelemahan pelaksanaan Sistem Jaminan Sosial bidang kesehatan di Kabupaten Kotawaringin Barat adalah belum adanya Pedoman Penyelenggaraan Program JKN dengan Kepesertaan BPJS; Masih rendahnya kepercayaan masyarakat terhadap birokrasi pemerintah;Masih adanya kebingungan dari pihak penyelenggara Jaminan Kesehatan tentang mekanisme pelayanan dan teknis;Semakin membebani masyarakat;Adanya diskriminasi pelayanan dengan pemberlakuan kelas I, II dan III; Masih rendahnya mutu pelayanan pada fasilitas kesehatan sebagai penyelenggara program Jaminan Kesehatan Nasional (JKN); Sistem pembayaran mengakibatkan kekecewaan masyarakat; Prosedur pelayanan BPJS yang berbelitbelit, dan obat-obatan yang tidak dibiayai oleh BPJS; Masyarakat tidak mau membayar iuran apabila tidak jatuh sakit, dan oknum petugas fasilitas kesehatan yang memanfaatkan keterbatasan fasiltas kesehatan untuk mengarahkan pasien ke praktik dokter perseorangan maupun fasilitas kesehatan swasta; Struktur Hukum Sistem Jaminan Sosial Nasional Bidang Kesehatan belum Berbasis Nilai Keadilan.

\section{DAFTAR PUSTAKA}

\section{Buku:}

Dachroni. (2000). Penerapan Promosi Kesehatan dalam Pemberdayaan Keluarga. Jakarta: Depkes RI.

Friedman, L.M. (2009). System Hukum Dalam Perspektif Ilmu Sosial, The Legal System: A Sosial Science Perspektive. Bandung: Nusa Media.

Kertonegoro, S. (1987). Jaminan Sosial dan Pelaksanaannya di Indonesia. Cet II. Jakarta: Mutiara Sumber Widya.

Muchsin, dan Fadillah Putra. (2002). Hukum dan Kebijakan Publik. Malang: Averroes.

Santoso, U. (2014). "Rekonstruksi Sistem Jaminan Sosial Nasional Bidang Kesehatan Berbasis Nilai Kesejahteraan.” Jurnal Pembaharuan Hukum.

Siregar, A. (2008). Pedoman Pelaksanaan Promosi Kesehatan. Jakarta: Depkes RI.

Suharto, E. (2005). Membangun Masyarakat Memberdayakan Rakyat: Kajian Strategis Pembangunan Kesejahteraan Sosial dan Pekerjaan Sosial. Bandung: Refika Aditama.

Trihono. (2002). Badan Peduli Kesehatan Masyarakat. Jakarta: Depkes RI.

Yuliani, M. (2013). Menyongsong BPJS Kesehatan 2014, Jaminan Kesehatan. Jakarta: Hak Rakyat-Kewajiban Negara. 
Yustina, E.W. (2012). Mengenal Hukum Rumah Sakit. Bandung: Refika Aditama.

\section{Artikel Jurnal:}

Paruntu, D.N. (2015). Perlindungan Hukum Hak Kesehatan Warga Negara Berdasarkan Undangundang Nomor 24 Tahun 2011 Tentang Badan Penyelenggara Jaminan Sosial. Mimbar Keadilan, November.

Qumairi, R. (2014). Sinkronisasi Pasal 36 Ayat (2) Peraturan Presiden Nomor 12 Tahun 2013 Tentang Jaminan Kesehatan Terhadap Pasal 23 Ayat (1) Undang-undang Nomor 40 Tahun 2004 Tentang Sistem Jaminan Sosial Nasional Terkait Kerjasama Dengan Badan Penyelenggara Jaminan Sosial.” Jurnal Mahasiswa Fakultas Hukum Universitas Brawijaya, Februari.

Usman, S. (2013). Pelaksanaan Pemberian Pelayanan Kesehatan Rawat Jalan Tingkat Lanjutan Bagi Peserta Jamkesmas (Studi Implementasi Pasal 19 Ayat (2) Jo Pasal 20 Ayat (1) Jo Pasal 22 Ayat (1) Undang-undang Nomor 40 Tahun 2004 Tentang Sistem Jaminan Sosial Nasional di Rumah Sakit Umum Daerah Dr. Saiful Anwar Kota Malang).” Jurnal Mahasiswa Fakultas Hukum Universitas Brawijaya, Februari.

\section{Undang-undang dan Peraturan}

Peraturan Presiden Nomor 12 Tahun 2013 Juncto Peraturan Presiden Nomor 111 Tahun 2013 tentang Jaminan Kesehatan Nasional. t.t.

Undang-undang Dasar Negara Republik Indonesia Tahun 1945. t.t.

Undang-undang Nomor 23 Tahun 2014 tentang Pemerintah Daerah. t.t.

Undang-undang Nomor 24 Tahun 2011 tentang Pembentukan Badan Penyelenggara Jaminan Sosial. t.t.

Undang-undang Nomor 40 Tahun 2004 tentang Sistem Jaminan Sosial Nasional. t.t. 